\title{
Examining the Factors Affecting Family Participation in Preschool Education: The Teachers' Views
}

\author{
Sevilay Sarışık ${ }^{1}$, Salih Sarışık ${ }^{2}$
}

\section{ARTICLE INFO}

Article History:

Received 05.01.2020

Received in revised form

17.07.2020

Accepted

Available online 01.07.2021

\begin{abstract}
This study was carried out to determine the opinions of preschool teachers regarding the factors affecting family participation in pre-school education by considering their gender, age, educational status and professional years.The study area of the research consists of 27 preschool teachers working in the Sapanca District of Sakarya Province.In the research, 5 questions were asked to preschool teachers in order to determine the factors affecting family participation in preschool education. Since the interviews were conducted in a computer environment, the data were recorded digitally, then they were converted into written documents and the data were analyzed by means of descriptive analysis method.As a result of the research;It was observed that the primary factors affecting family participation in preschool education contributed to the development of the child. It was observed that working hours was an important factor as the reason for the majority of parents not participating in family participation activities. It was observed that the majority of family participation activities were in class activities. It was observed that that family participation activities generally increased self confidence. It was observed that school administrators generally support the effect on family participotion.
\end{abstract}

CTUARA Journal. All rights reserved

Keywords:

Family involvement, pre-school education, school-family cooperation

\section{INTRODUCTION}

It is the first environmental family that the child encounters when she opens her eyes to the world. The basic skills of the individual born to adapt to the society develop after his / her basic needs such as nutrition, shelter and protection are developed through his family (Ömeroğlu, 1994; Çağdaş and Seçer, 2006). The family institution is the child's first educational environment, and parents are the first teachers (Waanders, Mendez and Downer, 2007). Apart from the family, the place where the first social experiences of the child take place is preschool education institutions. The impact of the family continues in this period, which is the first phase of the education and training life and has great importance in the development of the individual

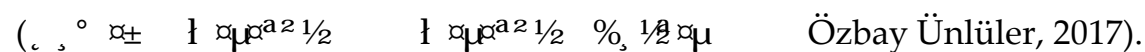

Preschool education institutions are institutions established to provide conscious assistance to the family in the education of the child, but the responsibilities of the family that sends their children to these institutions are shared with the teachers. In addition, the beginning of the child's learning life places extra responsibilities on the parents. The most important of these responsibilities is that the education in the institution where the child continues and the education at home support and overlap each other. In this context, parents need to have information about education in the institution and to cooperate with the institution (Oktay, 2002; Yazar, Çelik and Kök, 2008). Cooperation between the school and the family starts with the child's enrollment. Educators should learn the characteristics and family information of children on the first day of school and manage the education process in the light of the information they learn; organize the family involvement program, an important part of this process (Vural and Koçabaş, 2016).

Family involvement is the process of involving parents in the training program to support the development of both themselves and their children (Tezel Şahin and Ünver, 2005).

Purpose in family participation; To ensure the communication between the school and the family, to act together in the development and education of the children and thus to support the development and learning process. Another important aim of family participation is that by many researchers; to reduce the negative effects of the environment, especially on students with low socio-economic status (ex., Green, 2003; Decker and Decker, 2005; Meyer and Mann, 2006; Christine and Waanders, 2007).

When programming family participation, socio-economic, cultural, behavioral and developmental differences of families should be taken into consideration. Assuming that each difference constitutes a whole, family participation studies should be planned. Therefore, knowing the structure and characteristics

\footnotetext{
${ }^{1}$ Ministry of Education, sevilay.sarisik@ogr.sakarya.edu.tr, orcid.org/0000-0001-6750-4949
}

${ }^{2}$ Ministry of Education, salih.sarisik@ogr.sakarya.edu.tr, orcid.org/0000-0002-6506-2830 
of families is important for an effective family participation program (Aydoğan, 2017; Hohmann and Weikart, 2000).

Family participation in preschool period is mostly; information meetings, parent meetings, family participation in school programs, individual interviews, conferences, newsletters, phone calls, two-way correspondence, education announcement and bulletin boards, child's arrival and departure to school, booklets, brochures, photos, posters, video recordings, development report and observation forms, family library, wish box, family participation in the classroom (job promotion, activity, kitchen activities, Turkish language activities, etc.) and out of class activities, home visits, learning at home, inclusion of the family in decision-making processes (Aktaş Arnas, 2011; Temel, 2013; Varol, 2005; Ömeroğlu,2003).

It is seen that the educator and the preschool education institution have an important effect on the participation of the parents in the education process and the implementation of these activities (Kurtulmuş, 2016; Ünüvar, 2010). First, sociocultural studies should be planned to strengthen the school family solidarity by organizing family educational activities to recognize the family structure, establish family relations that will guide the planning and management of the educational process, and solve the problems that will arise in the learning process. Thus, it is thought that it will contribute to the solution of the difficulties that may arise in child rearing and education (Cömert and Güleç, 2004; Çakmak, 2010; Güler, 2014).

When studies on family participation in preschool education (Coleman 1987; Ma, Shen, Krenn, Hu, \& Yuan, 2016; Şahin \& Kalburan, 2009) were examined, it was found that parents' participation in education had a positive effect on children's development, cultural competence and academic success. However, it has been observed that families lead to the need to allocate more qualified time and support to their children and to ensure that what they learn at school is permanent (Çalık, 2007; Güleç ve Genç, 2010). According to the study conducted by Marcon (1999) with the families of low-income four-year-old children, it was concluded that the academic development of the children was positively affected by the contribution of the families to the school and their participation in education, and that the children showed a more positive development with the increase in the family participation. In this context, it was observed that they will have a positive effect on the development of the child and the communication of the parents and the children in the family participation activities based on the joint work of the schools and families (Murray, McFarland-Piazza and Harrison, 2015; Spiegel-McGill, Reed, Konig and McGowan, 1990).

When the literature is examined, an in-depth study of the first-hand experiences of pre-school teachers and teachers for family participation studies makes the research important. The study, which was designed in line with the mentioned importance, aims to reveal the perceptions of preschool teachers for family participation studies, the effects of family participation studies on children, and their views on family participation studies. In line with these goals, the current research aims to examine teachers' views on family participation studies implemented in pre-school education institutions.

What are the factors related to family participation in pre-school education according to the opinions of teachers?

The aim of the study is to examine the opinions of preschool teachers on the factors affecting family participation. It is thought that the findings that will emerge in the scope of this research will contribute to be a guide about family participation in order to share the common opinion with newly appointed preschool teachers.

In this context, "What is the level of suitability of pre-school teachers' knowledge and practices regarding family participation to the literature?" The answer to the question was sought.

1- What is family participation according to preschool teachers?

2- What are the activities that preschool teachers do about family participation in the education process?

3- According to preschool teachers, what are the reasons why parents with children in preschool institutions do not participate in family participation?

4- According to preschool teachers, what are the positive results of parents with children in preschool institutions to participate in family participation?

5- What are the attitudes of school administrators towards family participation according to preschool teachers? 
Parents should be considered as a basic element in making and extending preschool education useful. Parents are individuals who are more responsible for the happiness of children than anyone else. Parents are teachers of their children, even if they are not aware of it. No one can take these duties from them. Educational institutions provide responsibilities to meet the new needs of the child by providing opportunities that the family cannot offer. In other words, the school completes the educational activities of the parents. It is thought that school-family cooperation is necessary for this to happen. The positive development of school family relationships ensures that both parties are happy. With the positive communication established between the school and the family, they support the development of the child and also serve the goals of the school. School and family should be established in such a way that the child can grow up as a balanced, social, harmonious and happy individual in the positive environment created by this bond. In order to achieve this, the primary school, the school should be familiar with the family and consensus and cooperation on certain issues (Oral, 1997).

For a positive cooperation between school and family, we need to be aware of effective communication and interaction. It should not be forgotten that the effective and positive development of school-family interaction will be beneficial for both parties, rather than everyone, to the common interest, that is, children. Teachers and parents can overcome the barriers only in the consciousness of their interconnected and based tasks. It provides the family's trust in the school. Obtains information about the development areas of her/his child. When appropriate, parents' special interests, abilities, and family involvement can take place effectively. Families approach the child more consciously at home as a continuation of what children learn at school and prepare the child's learning environment at home. When school-family collaboration, families gain a lot from school and play an important role in children's education (Hale, 2001). In this context, the cooperation established between the school and the family, it is thought that parents will participate in the activities with the child at school, increase the child's self-esteem and love the school, and the family's cooperation with the school will make an original contribution. As a matter of fact, it is thought that the data obtained from this research can be very important for the field employees since family participation in the preschool period will contribute to the studies related to the development of the child. The research is limited to 27 pre-school teachers who are connected to the Ministry of National Education working in the district of Sapanca and have one-to-one interviews about family participation and the questions asked at the interview.

\section{METHOD}

In this study, "a semi-structured interview technique was used. This technique is defined as (Yıldırım\&Şimşek, 2008) the research in which qualitative data collection methods such as observation, interview, document analysis are used, and where a qualitative process is pursued to reveal perceptions and events in a realistic and holistic way"

In this study, the interview form, which was developed in order to determine the opinions of preschool teachers regarding factors affecting family participation by taking into consideration gender, age, educational status and professional year, was finalized in line with the opinions of the experts. There are five open-ended questions in the interview form.

\section{Study Group}

In this study, the study group was determined by an easily accessible sampling method. In this method, the researcher chooses a situation that is close and easily accessible and adds speed and practicality to the research (Yildırım \& Şimşek, 2008).

With the easily accessible sampling method in the research, 27 pre-school teachers working in the district of Sapanca in Sakarya constitute the working group of the research. 26 of the teachers constituting the working group are female and 1 is male. The average age of the teachers was calculated as 34.8 .

\section{Data Collection Tool}

In this study, interview forms were used as data collection tool. During the preparation phase of the interview questions, 5 open-ended questions that would best express the relevant sub-problems were 
prepared and written on the interview form. Open-ended research questions "provide the researcher with an flexible and open-ended approach to the subject that he wants to examine" (Yıldırım \& Şimşek, 2008).

The interviews were held on the dates and times determined according to the teachers' school hours. The interviews were written and recorded on the computer in order to avoid loss of data. During the interview, the teachers answered all 5 questions expressed and said their opinions.

\section{Questions}

1. What is family participation according to preschool teachers?

2. What are the activities that preschool teachers do about family participation in the education process?

3. According to preschool teachers, what are the reasons why parents with children in preschool institutions do not participate in family participation?

4. According to preschool teachers, what are the positive results of parents with children in preschool institutions to participate in family participation?

5. What are the attitudes of school administrators towards family participation according to preschool teachers?

\section{Data Analyses}

The data gained from the interviews were analyzed by descriptive analysis method. Descriptive analysis consists of four stages as creating a framework for descriptive analysis, processing data according to the thematic framework, defining findings and interpreting the findings (Yıldırım\&Şimşek, 2008).

The thematic framework was determined by the researchers for the analysis of the data. In this context, the data were first coded by each researcher. Then, common coding was made in common themes with the researchers' common views by comparing the data gathered.

The written texts formed as a result of the interviews were examined again and again, the data suitable for the purpose of the research were coded, and the themes, explaining the coded data at a general level, were determined.

The findings are arranged in tables. The interviewed teachers are coded starting from T1 to T27. In the interpretation of the findings, direct quotations from the views of the teachers were included.

\section{FINDINGS}

This section includes findings obtained as aresult of the research.

Opinions of pre-school teachers on factors affecting family participation.

The opinions of preschool teachers regarding the factors affecting family participation by taking into account gender, age, educational status and professional year are shown in tables below.

The opinions of preschool teachers on family participation are presented in Table 1.

Table 1. Pre-school teachers' views on family participation

\begin{tabular}{|c|c|c|c|}
\hline Theme (Categories) & Codes & $n$ & $\%$ \\
\hline & Contributing to the development of the child & & \\
\hline & (T1,T2,T3,T4,T12,T13,T14,T15,T16,T17,T19,T20,T21,T24) & 14 & 51,8 \\
\hline & School - Family cooperation strengthened & & \\
\hline & (T1,T7,T11,T12,T13,T15,T16,T17,T19,T21,T27) & 11 & 40,1 \\
\hline & Parents' observation of their children in the educational environment & 7 & 250 \\
\hline & (T1,T9,T10,T18,T19,T20,T25) & 7 & 20,9 \\
\hline \multirow[t]{7}{*}{ Family Involvement } & The family is in the education process (T2,T6,T8,T9,T14,T15,T26) & 7 & 25,9 \\
\hline & The child's positive attitude towards school (T4,T5,T11,T14,T20,T24) & 6 & 22,2 \\
\hline & The family is aware of the work at school $(\mathrm{T} 1, \mathrm{~T} 6, \mathrm{~T} 9, \mathrm{~T} 11, \mathrm{~T} 14, \mathrm{~T} 23)$ & 6 & 22,2 \\
\hline & Improving the self-confidence of the child (T1,T11,T14,T20,T24) & 5 & 18,5 \\
\hline & Contribution to parents (T3,T11,T13,T20,T26) & 5 & 18,5 \\
\hline & Strengthening the family-child relationship $(\mathrm{T} 4, \mathrm{~T} 5, \mathrm{~T} 14, \mathrm{~T} 20)$ & 4 & 14,8 \\
\hline & Ensuring that school work continues at home (T7,T27) & 2 & 7,4 \\
\hline
\end{tabular}


When Table 1 is examined, it is seen that the opinions of preschool teachers on family participation are most $51.8 \%$ as contributing to the development of the child. Other opinions are as follow: $40,7 \%$ school - Family cooperation strengthened, $25,9 \%$ parents' observation of their children in the educational environment, $25,9 \%$ the family is in the education process, $22,2 \%$ the child's positive attitude towards school, $22,2 \%$ the family is aware of the work at school, $18,5 \%$ improving the self-confidence of the child, $18,5 \%$ contribution to parents, $14,8 \%$ strengthening the family-child relationship and 7,4\% ensuring that school work continues at home. The exact quotations taken from the opinions of the teachers are presented below.

"I think family involvement is very useful. Both children's development areas are supported. It contributes to parents' awareness of what they can do by generating different ideas and developing their sense of trust. So I think participation is a must."(T3)

"Family participation provides support for the development and education of the child, and creates the opportunity to create an educational environment by taking into account the characteristics of the child through the communication and cooperation of the parents and teachers."(T17)

"I care about family participation. Communication with the family is very important in terms of contributing to the child's self-confidence and development. Family participation studies are provided for these developments. The parent observes the child's situation in the classroom. Be aware of education and work at school."(T1)

"It is indispensable for preschool education. Verbal or written information is given about educational activities in the classroom. However, parents' involvement in the implementation process and observation on site make family participation very important."(T9)

Family participation activities implemented by preschool teachers are presented in Table 2.

Table 2. Family participation activities implemented by preschool teachers

\begin{tabular}{clcc}
\hline \multicolumn{1}{c}{ Codes } & $n$ & \% \\
\hline Theme (Categories) & \multicolumn{1}{c}{ In-class activities } & 27 & 100 \\
& (T1,T2,T3,T4,T5,T6,T7,T8,T9,T10,T11,T12,T13,T14,T15 & & \\
& T16,T17,T18,T19,T20,T21,T22,T23,T24,T25,T26,T27) & 7 & 25,9 \\
Family involvement & Information meetings (T7,T8,T15,T16,T17,T20,T26) & 6 & 22,2 \\
activities implemented & Excursion events (T12,T16,T17,T18,T21,T22) & 5 & 18,5 \\
& Home visits (T8,T15,T16,T17,T27) & 4 & 14,8 \\
& Information letters (T7,T13,T16,T17) & 3 & 11,1 \\
& Individual interviews (T13,T15,T16) & 3 & 11,1 \\
& Informing families (T1,T13,T17) & & \\
& & &
\end{tabular}

When Table 2 is analyzed, it is seen that the opinions of the preschool teachers about the family participation activities implemented are $100 \%$ in the classroom activities. Other opinions are as follow: $25,9 \%$ information meetings, $22,2 \%$ excursion events, $18,5 \%$ home visits, $14,8 \%$ information letters, $11,1 \%$ individual interviews and Informing families. The exact quotations taken from the opinions of the teachers are presented below.

"In-class activities (simple art events, culinary events, experiments, stories, riddles, drama events, traditional games), parent meetings, information sharing during check-in and out via phone, trips, informative notes, family visits."(T17)

"I send the meetings and information letters to the family according to the importance of preschool, the information about the children and the subjects they filled in the form that we sent with the name of "family participation form" at the beginning of the year Storytelling by calling the guardian class, planting saplings, brewing yogurt, making small cakes, making bird feeders on trees, grass man, fruit salad, apple candies, experiment studies."(T7)

"Profession-hobby-skill introductions Family participation activities at home (preparing presentation on the given subject and presenting in the classroom) Taking part in trips in social-cultural activities Build-bring-tell etc. Changing and varying events every year."(T12)

"Information meetings, communication techniques, home visits, class visits, home events, various presentation events, etc." (T8) 
According to the teachers, the reasons why parents are not involved in family participation activities are presented in Table 3.

Table 3. According to teachers, reasons why parents do not participate in family participation activities

\begin{tabular}{|c|c|c|c|}
\hline Theme (Categories) & Codes & $n$ & $\%$ \\
\hline \multirow{6}{*}{$\begin{array}{l}\text { Reasons for not } \\
\text { participating in family } \\
\text { participation }\end{array}$} & $\begin{array}{l}\text { Working hours of parents } \\
(\mathrm{T} 1, \mathrm{~T} 2, \mathrm{~T} 3, \mathrm{~T} 7, \mathrm{~T} 8, \mathrm{~T} 9, \mathrm{~T} 11, \mathrm{~T} 12, \mathrm{~T} 13, \mathrm{~T} 14, \mathrm{~T} 15, \mathrm{~T} 16, \mathrm{~T} 17, \mathrm{~T} 19, \mathrm{~T} 20, \mathrm{~T} 21, \mathrm{~T} 23)\end{array}$ & 20 & 74 \\
\hline & $\begin{array}{l}\text { The indifference of families } \\
\text { (T2,T3,T4,T6,T7,T12,T13,T15,T16,T17,T19,T20,T22,T23,T26,T27) }\end{array}$ & 16 & 59,2 \\
\hline & $\begin{array}{l}\text { Family feeling inadequate } \\
\text { (T3,T4,T5,T8,T9,T12,T14,T16,T17,T21,T22,T23,T24,T27) }\end{array}$ & 14 & 51,8 \\
\hline & Having family causes & 12 & 44 \\
\hline & (T2,T4,T7,T8,T9,T12,T14,T15,T16,T17,T21,T25) & & \\
\hline & Parents not being adequately informed (T1,T12,T17,T22) & 4 & 14,8 \\
\hline
\end{tabular}

When Table 3 is analyzed, it was seen that the opinions of the parents regarding the reasons for not participating in family participation activities were at most $74 \%$ in the form of working hours of the parents. Other opinions are as follow: 59,2\% the indifference of families, 51,8\% family feeling inadequate, $44,4 \%$ having family causes and 14,8\% parents not being adequately informed. The exact quotations taken from the opinions of the teachers are presented below.

"The busy working hours are not suitable, the parent who does not know what to do does not want to participate due to anxiety."(T24)

"Parents' failure to show the necessary attention to preschool education period, the family feeling inadequate, working hours do not comply, the lack of communication between the school and the family, the importance of this process and how it will work."(T17)

"Some parents think that their educational responsibilities are over when children start school. Considering that this responsibility belongs only to the school."(T12)

"Since he / she is someone at home (baby or elderly), he / she cannot leave the house, regard it as unnecessary or care, fear of not being able to do the activity (lack of self-confidence), spouse's consent."(T4)

According to teachers, positive results of parents' participation in family participation activities are presented in Table 4.

Table 4. Positive results of parents' participation in family involvement activities, according to teachers

\begin{tabular}{|c|c|c|c|}
\hline Theme (Categories) & Codes & $n$ & $\%$ \\
\hline \multirow{10}{*}{$\begin{array}{l}\text { Positive results of } \\
\text { family involvement }\end{array}$} & $\begin{array}{l}\text { Increased self-confidence of the child } \\
(\mathrm{T} 2, \mathrm{~T} 3, \mathrm{~T} 8, \mathrm{~T} 10, \mathrm{~T} 11, \mathrm{~T} 13, \mathrm{~T} 15, \mathrm{~T} 16, \mathrm{~T} 17, \mathrm{~T} 19, \mathrm{~T} 20, \mathrm{~T} 25, \mathrm{~T} 26)\end{array}$ & 13 & 48,1 \\
\hline & $\begin{array}{l}\text { Parents' positive attitude towards school } \\
(\mathrm{T} 2, \mathrm{~T} 3, \mathrm{~T} 7, \mathrm{~T} 9, \mathrm{~T} 12, \mathrm{~T} 14, \mathrm{~T} 16, \mathrm{~T} 20, \mathrm{~T} 24)\end{array}$ & 9 & 33,3 \\
\hline & $\begin{array}{l}\text { Parent's view of the classroom environment } \\
(\mathrm{T} 1, \mathrm{~T} 3, \mathrm{~T} 9, \mathrm{~T} 15, \mathrm{~T} 17, \mathrm{~T} 20, \mathrm{~T} 22, \mathrm{~T} 23)\end{array}$ & 8 & 29,6 \\
\hline & Teacher's getting to know the family (T1,T3,T4,T8,T15,T16,T17,T23) & 8 & 29,6 \\
\hline & $\begin{array}{l}\text { Parent's awareness of the work at school } \\
(\mathrm{T} 5, \mathrm{~T} 7, \mathrm{~T} 9, \mathrm{~T} 12, \mathrm{~T} 14, \mathrm{~T} 16, \mathrm{~T} 27)\end{array}$ & 7 & 25,9 \\
\hline & Increased interest of the child in school (T7,T11,T12,T15,T17,T20) & 6 & 22,2 \\
\hline & Strengthening the child-family bond (T4,T13,T14,T20,T21,T27) & 6 & 22,2 \\
\hline & Ensuring continuing education (T6,T8,T14,T27) & 4 & 14,8 \\
\hline & Parent's empathy with the teacher (T9,T14,T18,T20) & 4 & 14,8 \\
\hline & Supporting the development of the child $(\mathrm{T} 1, \mathrm{~T} 8)$ & 2 & 7,4 \\
\hline
\end{tabular}

When Table 4 is analyzed, it was seen that according to teachers, the positive results of parents' participation in family involvement activities were $48.1 \%$, in the form of increased self-confidence. Other opinions are as 
follow: 33,3\% parents' positive attitude towards school, 29,6\% parent's view of the classroom environment, $29,6 \%$ teacher's getting to know the family, $25,9 \%$ parent's awareness of the work at school, $22,2 \%$ increased interest of the child in school and strengthening the child-family bond , $14,8 \%$ ensuring continuing education and parent's empathy with the teacher and 7,4\% supporting the development of the child. The exact quotations taken from the opinions of the teachers are presented below.

"Family involvement activity is important in terms of improving children's self-esteem and being happy."(T10)

"The child's sense of belonging to the class increases, parents' attitudes towards school are positively affected."(T2)

"Parents' awareness of pre-school education is increasing. Children have the opportunity to observe in the classroom environment, in the peer group. They have the opportunity to monitor and experience the educational activities of the teacher. They can empathize with the teacher in problems that may arise in the future."(T9)

"I believe that it contributes to the development of children's self-esteem, provides permanent learning, and supports the educational and developmentally of children, the teacher contributes positively to the child to know the family better and to increase efficiency."(T23)

According to the teachers' opinions, the attitudes of school administrators about family participation are presented in Table 5.

Table 5. According to the opinions of the teachers, attitudes of school administrators towards family participation

\begin{tabular}{clcc}
\hline Theme (Categories) & \multicolumn{1}{c}{ Codes } & $\boldsymbol{1}$ & \multicolumn{1}{c}{$\%$} \\
\hline & Supports (T1,T3,T4,T8,T9,T10,T13,T14,T18,T19,T20,T21,T22 & 18 & 66,6 \\
& T23,T24,T25,T26,T27) & 4 & 14,8 \\
& Not supported (T7,T15,T16,T17) & & 14,8 \\
\multirow{2}{*}{$\begin{array}{c}\text { Attitudes of school } \\
\text { administrators }\end{array}$} & Family not aware of the importance of participation & 4 & \\
& (T11,T12,T16,T17) & 2 & 7,4 \\
& Promotes (T2,T5) & 2 & 7,4 \\
& Puts the advertisement of the school in the foreground (T6,T7) & 1 & 3,7
\end{tabular}

When Table 5 is examined, it is seen that school administrators support attitudes towards family participation at the rate of $66.6 \%$ according to the opinions of teachers. Other opinions are as follow: $14,8 \%$ not supported and family not aware of the importance of participation, $7,4 \%$ promotes and puts the advertisement of the school in the foreground and 3,7\% focus on material size. The exact quotations taken from the opinions of the teachers are presented below.

"They support family participation efforts."(T26)

"School administrators do not interfere with family involvement, but do not show the necessary support and sufficient attention to involve the parent in the educational process."(T17)

"They focus more on the financial aspect of family participation effort. They do not have enough information about the contribution of family participation studies to the education process. They are not aware that continuity in education provides diversity."(T12)

"Encourages family participation, strives to prepare appropriate participation environments."(T2)

\section{RESULT AND DISCUSSION}

The results reached in the research conducted in order to examine the opinions of preschool teachers on factors affecting family participation by considering gender, age, educational status and professional year can be summarized as follows:

1.Pre-school teachers' views on family participation contributed to the development of $51.8 \%$ of children, $40.7 \%$ strengthened school-family cooperation, $25.9 \%$ of the parents observed their children in the educational environment and the family's education process, $22.2 \%$ of the children The school's positive attitude towards the school and the family's awareness of the work at school, $18.5 \%$ of the child's selfconfidence and contribution to the parents, $14.8 \%$ of the family-child relationship strengthened and $7.4 \%$ of the school's work to continue at home. 
2. Family participation activities implemented by preschool teachers are $100 \%$ in-class activities, $25.9 \%$ informative meetings, $22.2 \%$ excursion activities, $18.5 \%$ home visits, $14.8 \%$ informative writings, $11.1 \%$ There were individual interviews and family information.

3. According to the teachers, the reasons why parents do not participate in family participation activities are $74 \%$ of the parents 'working hours, $59.2 \%$ of the families' indifference, $51.8 \%$ of the families feeling inadequate, $44.4 \%$ of the family reasons and $14.8 \%$ of the parents are not sufficiently informed. It has been.

4. According to the teachers, the positive results of parents' participation in family participation activities are $48.1 \%$, the self-confidence of the child increases, $33.3 \%$ of the parents develop a positive attitude towards the school, $29.6 \%$ of the parents enter the classroom environment and the teacher knows the family, $25.9 \%$ of the parents The awareness of the studies was the increase in the interest of the child to the school by $22.2 \%$ and the strengthening of the child-family bond, the continuation of the education by $14.8 \%$, and the parents' empathy with the teacher and the development of the child by $7.4 \%$.

5. According to the teachers 'views, they support $66.6 \%$ of school administrators' attitudes towards family participation, do not support $14.8 \%$ and are not aware of the importance of family participation, encourage $7.4 \%$ and prioritize the school's advertising and $3.7 \%$ material has been focusing.

According to the results of the research, it was observed that preschool teachers contributed to the development of the child at the beginning of their views on family participation. All of the family involvement activities implemented by preschool teachers were considered as in-class activities. Working hours of parents were seen as a factor that had a large impact on participating in family participation activities, according to teachers. According to teachers, parents' involvement in family involvement activities is thought to have positive consequences, such as improving the child's self-confidence. It is seen that school administrators generally support family participation activities. When studies on family participation in preschool education are examined; It was determined that parents did not spend enough time on their children's educational activities and that they had some obstacles in this regard. It has been observed that the working hours of the disabled, the strict working hours, the number of children that the family has, and the density of the housework are specified by the parents. When the literature is examined, it is possible to find many studies supporting these findings.

For example, Hornby and Lafaele (2011) state that some parents do not have the appropriate working hours to participate in family involvement activities at school, and some parents are too tired when returning from work, so they cannot support their children's home activities. Hoover-Dempsey and Joan (2002) stated that time constraints for teachers and parents pose a problem for family participation. This also supports our research.

Family participation studies have improved that parents develop positive attitudes in school (Ihmeideh \& Oliemat, 2015; Koçyiğit, 2015; La Paro et al., 2003), economic developmental and academic average positive stars are supported (Kartal, 2007; Ma et al, 2016; Mazer and Thompson , 2017; Nitecki, 2015), however, it has been stated by preschool teachers that the transformation of the society that parents are involved in the family participation studies is effective (Ferrara, 2015; Stevens \& Patel, 2015; Temel \& Aksoy, 2000). This also supports our research.

In Iş1k's (2007) study on the examination of family participation activities carried out in preschool education institutions based on parental opinions, it was determined that the family participation studies, which are frequently included by the preschool education institution, are face-to-face interviews, however, parents' meetings are planned throughout the year. However, it was observed that the school did not have much room for communication, conferences and seminars, home visits, wish-complaints box and family meeting and socializing meetings. It was observed that these views overlap with the findings of the research. In the study, the opinions of the teachers about the reasons that families do not / prefer not out-of-school activities for various reasons were preferred. When the reasons for this situation were investigated, teachers' opinions were determined that the out-of-school environments are not safe and seasonal conditions are not suitable, transportation problems, parents have negative thoughts about out-of-class activities, and parents cannot spare time due to their workload. The reason for this finding may be due to the fact that out-of-school learning is not common in preschool education, preschool teachers do not inform families about these 
activities as much as necessary and teachers do not cooperate adequately with administrators and parents. Some factors, such as administrators supporting out-of-school activities, may have caused parents to prefer classroom activities more.

In the studies of Tatar and Bağriyanık (2012), it was revealed that family participation was very important in out-of-school education activities, and it caused teachers not to prefer out-of-school education activities especially for certain reasons such as getting permission. Aydemir and Toker Gökçe (2016) stated that the school administration had problems in the field of self-care skills such as toilet and nutrition in out-of-school activities in basic education; they stated that they thought parents' permits and official letters were a problem. As can be seen in the studies, some factors such as the removal of the official dimension, support of teachers in various fields such as transportation, safety, nutrition, and administrators 'and teachers' positive attitudes and thoughts about out-of-school learning in order to enable families to engage in activities outside the classroom. It is seen that it is important in realization. These situations may have prevented family involvement activities outside the classroom. Teachers think that family participation studies contribute to children's permanent learning and self-confidence. In this process, they reported that both children and family and the teacher learned new things. This finding obtained from the study is similar to the results of the study conducted by Sağlam and Çalışkan (2017). In this study, the parents and teachers who participated in the research; it was determined that family participation activities are important for children, increase selfconfidence in children, strengthen the parent-child and teacher relationship, and have high awareness about the effects of family participation of teachers and parents on the child. It is very important for preschool teachers to have awareness that family participation is beneficial for meeting children's needs (Atakan, 2010; Çamlıbel Çakmak, 2010; Ömeroğlu \& Can Yaşar, 2003). In his research on family participation in education in pre-school education institutions, Eğmez (2008) found that school administrations do not prefer to organize seminars, conferences and similar educational activities, but they organize monthly bulletins, posters, brochures and news boards and support the teachers in this regard. These findings support the research.

As a result, the findings obtained from the research show similarities with the findings of other studies. When evaluated in general, it is seen that parents sometimes or always participate in organized family participation activities, and that their participation is beneficial both for themselves and for the development of their children. It is noteworthy that the reasons for not participating families are mostly related to "frequency of work and time". ; As long as the problem with work status and timing is resolved, the rate of parents' participation in family participation activities will increase.

\section{SUGGESTIONS}

1.Parents of various cultures, such as immigrant parents, to participate in preschool education activities; Trainings for these families can be organized through relevant institutions to ensure that they interact effectively with teachers and their surroundings.

2. It may be suggested to design, implement and ensure enriched in-class and out-of-class family participation activities by considering the characteristics of families before school.

3. About the planning, implementation and evaluation of out-of-school activities for preschool teachers; apart from vocational promotion and excursions, trainings can be given about organizing various family participation studies in different out-of-school settings.

4. In this context, supportive education policies of administrators for family participation activities can be established.

5. By increasing the knowledge levels of parents about preschool education, the quality and number of family participation studies can be increased.

6. Within the scope of the research, information related to the social and problematic behaviors of children was partially obtained from teachers. In the new researches to be conducted, getting information from the sources such as parents, guidance specialist who are in direct contact with the child together with the teachers will increase the reliability of the findings. 


\section{REFERENCES}

Akaya, M. (2007). Öğretmenlerin ve ebeveynlerin okul öncesi eğitim kurumlarında uygulanan aile katılımı çalışmalarına ilişkin görüşleri. Eskişehir: Anadolu Üniversitesi Eğitim Bilimleri Enstitüsü.

Aktaş, Y. (2011). Aile eğitimi ve okul öncesinde aile katılımı. Ankara: Vize Yayıncılık.

Atakan, H. (2010). Okul öncesi eğitiminde aile katılımı çalı̧̧malarının öğretmen ve ebeveyn görüşlerine göre değerlendirilmesi. Çanakkale Onsekiz Mart Üniversitesi Sosyal Bilimler Enstitüsü, Çanakkale.

Aydemir, İ. \& Toker Gökçe, A. (2016). Okul yöneticilerinin okul dışı öğrenme ortamlarına ilişkin görüşleri. International Eurasian Educational Research Congress.

Aydoğan, Y. (2017). Okul öncesi eğitim programlarında aile katılımı. Ankara: Pegem

Bursalığlu, Z (2000). Eğitimde Yönetimi Anlamak Sistemi Çözümlemek. Pegem Akademik Yayıncılık.

Christine Waanders, Julia L. Mendez, Downer, J.T.(2007). Parent characteristics, economic

stress and neighborhood context as predictors of parent involvement in preschool

children's education. Journal of School Psychology, 45, 619-636.

Coleman, J. S. (1987). Families and schools. Educational Researcher, 16(6), 32-38.

Cömert, D. \& Güleç, H. (2004). Okul öncesi eğitim kurumlarında aile katılımının önemi: Öğretmen-AileÇocuk ve Kurum. Afyon Kocatepe Üniversitesi Sosyal Bilimler Enstitüsü Sosyal Bilimler Dergisi, 6(1), 131145.

Çağdaş, A. \& Seçer, Z. (2006). Anne-baba eğitimi (2.baskl). Ankara : Kök Yayıncllık

Çakmak, Ö. Ç. (2010). Okul öncesi eğitim kurumlarında aile katılımı. Abant İzzet Baysal Üniversitesi Sosyal Bilimler Enstitüsü Dergisi, 1(20), 1-18.

Çamlıbel Çakmak, Ö. (2010). Okul öncesi eğitim kurumlarında aile katılımı. Abant İzzet Baysal Üniversitesi Sosyal Bilimler Enstitüsü Dergisi, 20(20), 1-18

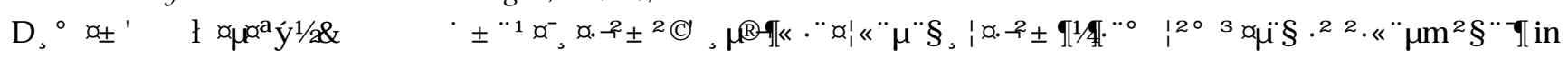
Different Countries. International Journal of Educational Research Review , 1 (1) , 1-13

Eğmez, K. (2008). Okul öncesi eğitim kurumlarında ailenin eğitime katılımı. Yayınlanmamış Yüksek Lisans Tezi, Sakarya Üniversitesi Sosyal Bilimler Enstitüsü, Sakarya

Green, S.(2003). Reaching out to fathers: An examination of staff efforts that lead to greater father involvement in early childhood programs. Early Childhood Research Practice, Vol. 5 No. 2

Güler, Ç. Y. (2014). Okul aile işbirliği: Öğretmen adaylarını ailelerle çalışmaya yeterince hazırlayabiliyor muyuz? Manisa Celal Bayar Üniversitesi Sosyal Bilimler Dergisi, 12(4), 72-90.

Ferrara, M. M. (2015). Parent involvement facilitators: Unlocking social capital wealth. School Community Journal, 25(1), 29-51.

Hale, D. (2001). Okul öncesi eğitimin ilke ve yöntemleri, Ankara: Anı Yayınc1lık

Hohmann, M. \& Weikart, D. P. (2000). Küçük çocukların eğitimi. İstanbul, Hisar Eğitim Vakfı Yayınları.

Hoover-Dempsey, K. V., \& Joan, M. T. (2002). Family-school comunication. Vanderbilt University.

Hornby, G. \& Lafaele, R. (2011). Barriers to parental involvement in education: An explanatory model. Educational Review, 63(1), 37-52.

Ihmeideh, F., \& Oliemat, E. (2015). The effectiveness of family involvement in early childhood programmes: Perceptions of kindergarten principals and teachers. Early Child Development and Care, 185(2), 181197.

Işık, M. (2007). Anasınıfina devam eden beş-altı yaş çocuklarına sosyal uyum ve beceri ölçeğinin uyarlanması ve uygulanması. Yayınlanmamış Yüksek Lisans Tezi. Gazi Üniversitesi, Ankara.

Kartal, H. (2007). Erken çocukluk eğitimi programlarından anne-çocuk eğitim programı'nın altı yaş grubundaki çocukların bilişsel gelişimlerine etkisi. Ilkögretim Online, 6(2), 234-248

Karagöz, S. \& Rüzgar, M.E.(2020).The observations of student teachers in regard to professional qualifications of advisor teachers during teaching practicum. International Journal of Educational Research Review,5(2),141-150 
Kurtulmuş, Z. (2016). Okul öncesi eğitimde uygulanan etkinlik planlarında aile katılımı boyutunun incelenmesi. Cumhuriyet International Journal of Education, 5(1), 71-84.

La Paro, K. M., Kraft-Sayre, M., \& Pianta, R. C. (2003). Preschool to kindergarten transition activities: Involvement and satisfaction of families and teachers. Journal of Research in Childhood Education, 17(2), 147-158.

Ma, X., Shen, J., Krenn, H. Y., Hu, S., \& Yuan, J. (2016). A meta-analysis of the relationship between learning outcomes and parental involvement during early childhood education and early elementary education. Educational Psychology Review, 28(4), 771-801.

Mazer, J. P., \& Thompson, B. (2017). The validity of the parental academic support sale: Associations among relational and family involvement outcomes. International Journal of Quantitative Research in Education, 4(1-2), 120-132.

Meyer, James A.ve Mann, Mary Beth (2006). Teachers' perceptions of the benefits of home visits for early elementary children. Early Childhood Education Journal, Vol. 34, No.1.s.93-97.

Morrison, G. S. (2003). Fundamentals of early childhood education. (3. Edition). Ohio: Merrill Prentice Hall.

Murray, E., McFarland-Piazza, L., \& Harrison, L. J. (2015). Changing patterns of parent-teacher communication and parent involvement from preschool to school. Early Child Development and Care, 185(7), 1031- 1052.

Nitecki, E. (2015). Integrated school-family partnerships in preschool: Building quality involvement through multidimensional relationships. School Community Journal, 25(2), 195-219.

Oral, O. (1997). Okul öncesi eğitimi, İstanbul: M.E.B. Yayınları

Oktay, A. (2002). Yaşamın sihirli yılları: Okul öncesi dönem. İstanbul: Epsilon Yayıncılık.

Ömeroğlu, E. (1994). Ailenin çocuğun eğitimine katılımı. Okul öncesi Eğitimi,47(3), Ankara.

Ömeroğlu, E., Yazıcı, Z. \& Dere. H. (2003). Okul öncesi eğitim kurumlarında ebeveynin eğitime katılımı, erken çocuklukta gelişim ve eğitimde yeni yaklaşımlar. İstanbul, Morpa Kültür Yayınları.

Ömeroğlu, E. ve Can Yaşar, M. (2005). Okul öncesi eğitim kurumlarında ailenin eğitime katılımı.

Bilim ve Aklın Aydınlığında Ĕ̆itim Dergisi, 6(62), 29-34.

Özbay Ünlüler, E. (2017). Okul öncesi eğitimde ailenin yeri ve önemi. Ankara: Pegem.

Razon, N. (1987). Okul öncesi çocukta sık rastlanan uyum ve davranış sorunlarından bazıları ve anaokulunda çözüm. 5. YA-PA Okul öncesi yayginlaştırılması semineri. Antalya: Ya-pa yayınları, 73-85.

Sağlam, M. \& Çalışkan, Z. (2017). Okul öncesi eğitimde aile katılımına ilişkin ebeveyn ve öğretmen görüşlerinin değerlendirilmesi, Uluslararası Erken Çocukluk Eğitimi Çalışmaları Dergisi, 2(2), 39-49.

Spiegel-McGill, P., Reed, D. J., Konig, C. S., \& McGowan, P. A. (1990). Parent education: Easing the transition to preschool. Topics in Early Childhood Special Education, 9(4), 66-77.

Stevens, S., \& Patel, N. (2015). Viewing generativity and social capital as underlying factors of parent involvement. School Community Journal, 25(1), 157-174.

Şahin, F. T., \& Kalburan, F. N. C. (2009). Aile eğitim programları ve etkililiği: Dünyada neler uygulanıyor? Pamukkale Üniversitesi Egĭtim Fakültesi Dergisi, 25(25), 1-12.

Tatar, N. \& Bağrıyanık, K. E. (2012). Fen ve Teknoloji dersi öğretmenlerinin okul dışı eğitime yönelik görüşleri. İlköğretim Online, 11(4), 883-896.

Temel, Z. F. \& Aksoy, A.B. (2000). Home-based mother training program For 0-3 years of age and it's effects on home environment. Psychologie and Education, 25 (2), 51-58.

Temel, Z. F. (2013). Aile eğitimi ve erken çocukluk eğitiminde aile katılım çalışmaları. Anı Yayıncılık.

Tezel Şahin, F. \& Ünver, N. (2005). Okul öncesi eğitim programlarına aile katılımı. Kastamonu Eğitim Dergisi, 13(1), 23-30.

Türk Dil Kurumu, (2007). Türk Dil Kurumu, bilim ve sanat terimleri ana sözlügü. http://tdkterim.gov.tr/

Ünüvar, P. (2010). Aile katılımı çalışmalarına yönelik ebeveyn ve öğretmen görüşlerinin karşılaştırılması. Kastamonu Eğitim Dergisi, 18(3), 719-730. 
Varol, N. (2005). Aile eğitimi. Ankara: Kök Yayıncılık.

Vural, D. E. \& Kocabaş, A. (2016). Okul öncesi eğitim ve aile katılımı. Elektronik Sosyal Bilimler Dergisi, 15(59), 1174-1185.

Waanders, C., Mendez, J. L., \& Downer, J. T. (2007). Parent characteristics, economic stress and neighborhood context as predictors of parent involvement in preschool children's education. Journal of School Psychology, 45(6), 619-636.

Yazar, A., Çelik, M. \& Kök, M. (2008). Aile katılımının okul öncesi eğitimde ve 2006 Okul öncesi eğitim programındaki yeri. Sosyal Bilimler Enstitüsü Dergisi, 12 (2), 233-243.

\section{INTERVIEW FORM}

This study is carried out to determine and improve the current state of family participation in preschool period. In this process, the opinions of teachers who have an important role in the education of the child are needed. There is no right or wrong answer to the questions asked within the scope of the study. Therefore, you are expected to answer the answers in line with your thoughts and teaching life. In the study, your personal information will be kept confidential and will not be shared with third parties / institutions under any circumstances. Thank you for your help and contributions.

$\begin{array}{lll}\text { Gender: } & \text { Age: } & \text { Year of Seniority: }\end{array}$

\begin{tabular}{|c|l||}
\hline ON & \multicolumn{1}{|c||}{ TEACHER INTERVIEW QUESTIONS } \\
\hline \hline $\mathbf{1}$ & What are your views on family participation? \\
\hline $\mathbf{2}$ & What are the activities you have done with family participation in the education process? \\
\hline $\mathbf{3}$ & What do you think are the reasons why parents do not participate in family participation activities? \\
\hline $\mathbf{4}$ & What are the positive results of parents' participation in family participation activities? \\
\hline \hline $\mathbf{5}$ & What are school administrators' attitudes towards family participation? \\
\hline
\end{tabular}

